\title{
Arsenic removal properties by electrolyzed and calcined manganese dioxide
}

\author{
Yong-Jun Jung ${ }^{1,2^{\dagger}}$, Yuki Kamimoto ${ }^{1}$ \\ ${ }^{1}$ Institute of Materials Innovation, Institutes of Innovation for Future Society, Nagoya University, Nagoya, 464-8603, Japan \\ ${ }^{2}$ Department of Environmental engineering, Catholic University of Pusan, 9 Bugok3-dong, Busan, 609-757, Korea
}

\begin{abstract}
$\mathrm{As}(\mathrm{V})$ removal properties of manganese dioxides which are commonly used for the removal of manganese in water treatment processes were evaluated in this paper. The following manganese dioxides were used: two types of powdered manganese dioxides powdered or electrolyzed $\mathrm{MnO}_{2}$ (g-structure) and calcined $\mathrm{MnO}_{2}$ (b-structure), and a granular $\mathrm{MnO}_{2}$, which was prepared by coating $\mathrm{MnO}_{2}$ onto a ceramic particle. The maximum arsenate adsorption capacity of the electrolyzed and calcined $\mathrm{MnO}_{2}$ was 2.22 and $2.26 \mathrm{mg}$-As g ${ }^{-1}$, respectively. The adsorption capacity of the granular $\mathrm{MnO}_{2}$ was $0.543 \mathrm{mg}$-As g-1 and this value corresponded to the $\mathrm{MnO}_{2}$ content $(23.2 \%)$ of the granular adsorbent. When an arsenate solution of $0.1 \mathrm{mg}$-As L ${ }^{-1}$ was fed into the column (10 mm i.d.; $100 \mathrm{~mm}$ long) packed with the granular $\mathrm{MnO}_{2}$ at $\mathrm{SV}=20 \mathrm{~h}^{-1}$, the column received $28.9 \mathrm{~L}$ of the feed solution (3,580 times the bed volume) before the breakthrough point $\left(0.01 \mathrm{mg}\right.$-As $\left.\mathrm{L}^{-1}\right)$. The adsorption isotherms for the electrolyzed and granular $\mathrm{MnO}_{2}$ were approximated by the modified Langmuir equations. On the other hand, the adsorption isotherm for the calcined $\mathrm{MnO}_{2}$ was approximated by the Freundlich equation. Based on the adsorption isotherms, the As $(\mathrm{V})$ adsorption amounts at 0.01 mg-As $\mathrm{L}^{-1}$ of the equilibrium concentration were evaluated as follows: $1.27 \mathrm{mg}$-As g${ }^{-1}$ for the electrolyzed $\mathrm{MnO}_{2}, 1.20 \mathrm{mg}^{-A s} \mathrm{~g}^{-1}$ for the calcined one, and $0.29 \mathrm{mg}^{-\mathrm{As} \mathrm{g}^{-1}}$ for the granular one. Since granular $\mathrm{MnO}_{2}$ has been commonly used for the removal of manganese from water treatment systems, the process can be also applied to arsenate removal.
\end{abstract}

Keywords: Arsenic, Adsorption, Manganese dioxide, Modified langmuir isotherm

\section{Introduction}

Ground water polluted by arsenic compounds occurs in many parts of the world, and many people have been exposed to the risk of their toxicity [1-4]. The international standards for an acceptable amount of arsenic in drinking water are regulated at $0.01 \mathrm{mg} \mathrm{L}^{-1}$ [5], and approximately 14.6 million people throughout the world are reported to suffer from drinking water that contains arsenic at $0.03 \mathrm{mg} \mathrm{L}^{-1}$ or highly [6]. Most cases are found in the developing countries. Meng et al. [7] described that $22 \%$ of the surveyed wells had an arsenic concentration of 100-250 $\mathrm{g} \mathrm{L}^{-1}$. Guo et al. [8] also reported that ground water containing $192.3 \mathrm{~g} \mathrm{~L}^{-1}$ of as caused severe clinical symptoms in China. Therefore, cost effective techniques for the removal of arsenic come from drinking water needed to be determined and developed.

The removal of arsenic compounds can be conducted by coagulation, adsorption, ion exchange, and membrane separation.
Aluminum sulfate and ferric sulfate are commonly used as a coagulant [7, 9-11], and this method can be applied to the treatment of household drinking water [8, 12], although a relatively large amount of sludge can be produced. Membrane separation, such as reverse osmosis, is one of promising technologies for the treatment of drinking water $[13,14]$. However, membrane separation process requires very expensive equipment, and the treatment of the retentate water produced in this process is necessary because arsenic is enriched in the retentate. The sorption processes have been applied to the removal of arsenic because of the following advantages: effective removal property, less sludge production, simple system arrangement, and easy operation.

Aluminum oxide and ferric oxides have been widely used in the removal of arsenic as an adsorbent [15-18]. Lanthanide compounds, such as cerium, yttrium, and lanthanum, have been developed as an effective adsorbent for arsenic [19-21], but they are very expensive. The following adsorbents and ion exchangers have
This is an Open Access article distributed under the terms of the Creative Commons Attribution Non-Commercial License (http://creativecommons.org/licenses/by-nc/3.0/) which permits unrestricted non-commercial use, distribution, and reproduction in any medium, provided the original work is properly cited.
Received August 13, 2019 Accepted October 16, 2019

${ }^{\dagger}$ Corresponding author

Email: yjjung@cup.ac.kr

Tel: +82-51-510-0625 Fax: +82-51-510-0628

Copyright (C) 2020 Korean Society of Environmental Engineers 
also been used: Activated carbon [22], titanium oxide [23], zirconia pillared montmorillonite [24], sand coated with iron oxide [25], ferrihydrite [17], hematite/feldspar [26], biopolymers [27], metal-loaded clay [28], combined ion exchanger [29], and natural loam soil [30].

Manganese dioxide was also suggested for the adsorption of arsenic. It was observed that $\mathrm{Mn}^{2+}$-rich hydrous manganese oxide accumulates arsenic in lake sediments [31] and that ferruginous manganese ore adsorbed arsenic [32]. In addition, Manganese dioxide was reported to be useful for the oxidation of $\mathrm{As}(\mathrm{III})$ to $\mathrm{As}(\mathrm{V})$ [33, 34]. Manganese dioxide has been commonly used for manganese removal in water treatment processes, where the water is chlorinated before it is fed into the manganese dioxide column. The above information suggests that conventional manganese removal process can be used for the removal of arsenic.

In this paper, manganese dioxide $\left(\mathrm{MnO}_{2}\right)$ as an adsorbent is focused on the removal of As (V). Two types of powdered $\mathrm{MnO}_{2}$ and one granular $\mathrm{MnO}_{2}$ were used. The effects of $\mathrm{pH}$ and the adsorption isotherms were examined. The removal capacity of the granular $\mathrm{MnO}_{2}$ was also examined by column adsorption experiments.

\section{Materials and Methods}

\subsection{Materials}

Two types of powdered manganese dioxides $\left(\mathrm{MnO}_{2}\right)$ were employed for the batch type adsorption experiments: Electrolyzed $\mathrm{MnO}_{2}$ (-structure, hexagonal) and calcined $\mathrm{MnO}_{2}$ ( $\beta$-structure, tetragonal) were prepared from the electrolyzed $\mathrm{MnO}_{2}$ calcinating at $350^{\circ} \mathrm{C}$ for $2 \mathrm{~h}$. The average particulate size of the powder $\mathrm{MnO}_{2}$ was $4.88 \mathrm{~m}$, where it was $7.77 \mathrm{~m}$ for $90 \%$ and $2.52 \mathrm{~m}$ for $10 \%$. The specific surface area was measured by a $\mathrm{N}_{2}$ gas adsorption isotherm at $77 \mathrm{~K}$ on the basis of the BET adsorption theory. The specific surface areas of the electrolyzed and calcined $\mathrm{MnO}_{2}$ were 83 and $8 \mathrm{~m}^{2} \mathrm{~g}^{-1}$, respectively. Granulated $\mathrm{MnO}_{2}$ was also used for both the batch type and column adsorption experiments. Granular $\mathrm{MnO}_{2}$ (average particle size: $0.4 \mathrm{~mm}$ ) was prepared by coating with calcined $\mathrm{MnO}_{2}$ and electrolyzed $\mathrm{MnO}_{2}$ (3:7) on a ceramic particle. The total content of $\mathrm{MnO}_{2}$ was $23.2 \%$. The particulate size of the granular $\mathrm{MnO}_{2}$ used in this study was a little smaller than that which is commonly used for the treatment of water (0.45-0.7 mm) [35].

A stock solution of $10 \mathrm{mg}$-As $\mathrm{L}^{-1}$ of sodium arsenate $\left(\mathrm{Na}_{2} \mathrm{HAsO}_{4} \cdot 7 \mathrm{H}_{2} \mathrm{O}\right)$ was prepared and diluted to an appropriate concentration for the experiments. The $\mathrm{pH}$ adjustment of the solution was carried out with dil- $\mathrm{HCl}$ and dil- $\mathrm{NaOH}$.

\subsection{Batch Type Adsorption Procedure}

The adsorption isotherms of the powdered $\mathrm{MnO}_{2}$ were obtained by batch type adsorption experiments under the following conditions: An appropriate amount of powdered adsorbent (0.02 to $0.55 \mathrm{~g}$ ) came into contact with $100 \mathrm{~mL}$ of an arsenic solution containing $5.0 \mathrm{mg}$-As $\mathrm{L}^{-1}$. The mixture was shaken longer than $2 \mathrm{~d}$ at $25^{\circ} \mathrm{C}$. The adsorbent in the mixed solution was removed by filtration with a H-PTFE membrane filter $(0.1 \mathrm{~m})$ and the arsenate concentration of the filtrate was analyzed by the membrane ex- traction-absorptiometric method for a visual determination with the detection tube method using molybdenum blue, which was developed in our laboratory [36] and it can detect $10 \mathrm{~g} \mathrm{~L}^{-1}$ of $\mathrm{As}(\mathrm{V})$ [27]. In the experiments, the $\mathrm{pH}$ level was not adjusted.

A similar procedure was employed for the granular adsorbent. $1 \mathrm{~g}$ of the adsorbent came into contact with a $100 \mathrm{~mL}$ solution (1.0 or 10 mg-As L $\mathrm{L}^{-1}$ ) for more than 1 week. Since a state of equilibrium was achieved within $5 \mathrm{~d}$, the experiments were conducted for the same length of time. The effects of co-existing anion on the removal of arsenate were examined by the addition of $\mathrm{Na}_{2} \mathrm{HPO}_{4}$ without $\mathrm{pH}$ adjustment, where $1.0 \mathrm{~g}$ of $\mathrm{MnO}_{2}, 100 \mathrm{~mL}$ of 10.0 mg- $\mathrm{PO}_{4}-\mathrm{PL}^{-1}$ and $100 \mathrm{~mL}$ of $10.0 \mathrm{mg}-\mathrm{AsL}^{-1}$ were employed. The effects of $\mathrm{pH}$ on the arsenate removal were also examined with the granular adsorbent.

\subsection{Column Adsorption Procedure}

Granular $\mathrm{MnO}_{2}$ was packed into a column (10 mm i.d.; bed height: $100 \mathrm{~mm}$; bed volume: $7.85 \mathrm{~cm}^{3}$ ). The arsenate solution of $0.1 \mathrm{mg}-\mathrm{As}$ $\mathrm{L}^{-1}$ was fed into the column under up-flow conditions, with a space velocity (SV) of 10 or $20 \mathrm{~h}^{-1}$. In the case of the common manganese removal process for water treatment, raw water is fed into SV $=30-15 \mathrm{~h}^{-1}$ for a column of 300-600 $\mathrm{mm}$ in height.

\section{Results and Discussion}

\section{1. pH Effects}

The effects of $\mathrm{pH}$ on the removal rate of arsenate with $\mathrm{MnO}_{2}$ were examined first with granular $\mathrm{MnO}_{2}$ as an adsorbent. The removal rate was significantly influenced by $\mathrm{pH}$, as shown in Fig. 1 . The removal increased with a decrease in the $\mathrm{pH}$ and stable removal rates (more than $80 \%$ ) were obtained with a $\mathrm{pH}$ range of less than 5.7.

The surface of hydrous $\mathrm{MnO}_{2}$ binds $\mathrm{H}^{+}$and $\mathrm{OH}^{-}$ions together and acts as an amphoteric hydroxide [37]. The $\mathrm{pH}$ of the point of zero charge (pHpzc) is ca. 2.8. The sorption of a cation such as $\mathrm{Mn}^{2+}$ on $\mathrm{MnO}_{2}$ occurs by the formation of surface complex or by an ion exchange. Since the exchange reaction releases $\mathrm{H}^{+}$ ion from the $\mathrm{MnO}_{2}$ surface, the sorption of a cation increases with

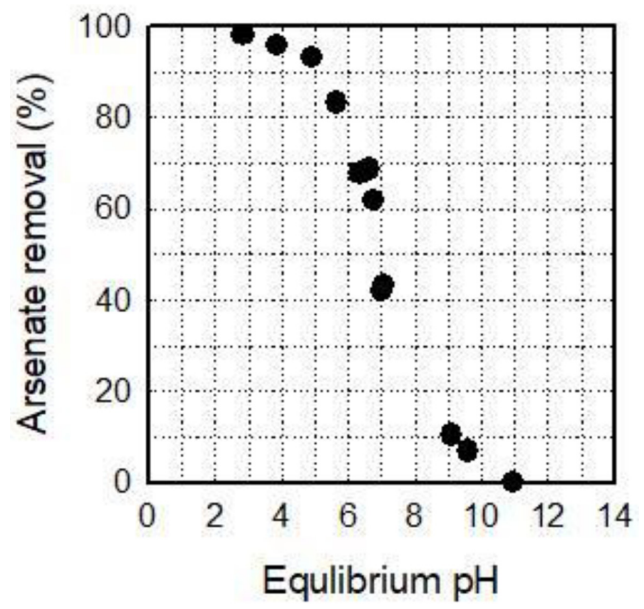

Fig. 1. Effects of $\mathrm{pH}$ on arsenate removal by granular $\mathrm{MnO}_{2}$. 
an increase in the $\mathrm{pH}$. On the other hand, since arsenate species are $\mathrm{H}_{2} \mathrm{AsO}_{4}{ }^{-}$and $\mathrm{HAsO}_{4}{ }^{2-}$ under experimental conditions, the sorption of the anions may be affected in an opposite way, with respect to the $\mathrm{pH}$. Therefore, the effect of $\mathrm{pH}$ on arsenate removal as shown in Fig. 1 may be interpreted by the properties of the $\mathrm{MnO}_{2}$ surface. Similar adsorption properties were observed for aluminum oxide [15] and ferric hydroxide [18].

Since the $\mathrm{pH}$ range of the arsenate solutions prepared in this work was between 5.49 and 6.35, the $\mathrm{pH}$ was not adjusted in the following experiments. When $\mathrm{MnO}_{2}$ is applied to the actual treatment, however, the $\mathrm{pH}$ may be adjusted.

\subsection{Adsorption Isotherm}

A state of equilibrium was attained for about $24 \mathrm{~h}$ as shown in Fig. 2. Saturated adsorption amounts were observed with more than 1 mg-As L ${ }^{-1}$ of the equilibrium concentration, as shown in Fig. 3. Their values were not significantly influenced by the type of $\mathrm{MnO}_{2}: 2.26$ mg-As g ${ }^{-1}$ for the calcined $\mathrm{MnO}_{2}$ and 2.22 mg-As $\mathrm{g}^{-1}$ for the electrolyzed $\mathrm{MnO}_{2}$.

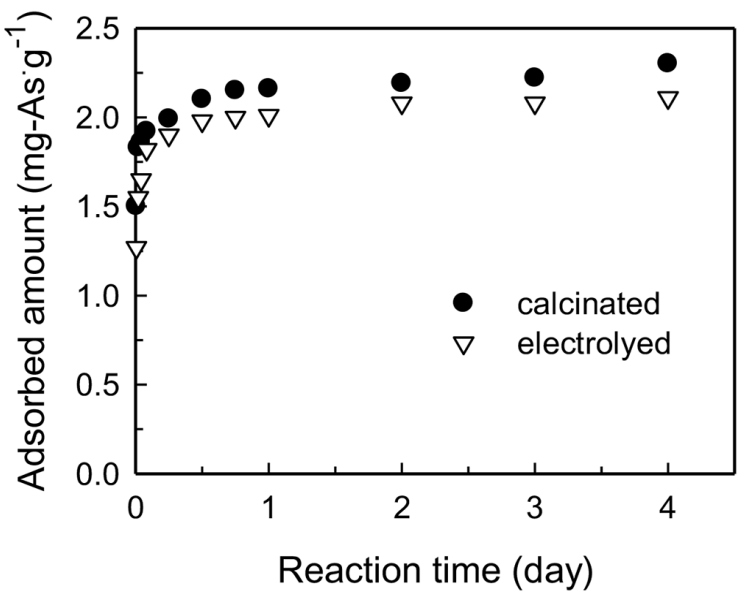

Fig. 2. Profiles of adsorbed amounts with contact time. Conditions: 0.02-0.55 g of $\mathrm{MnO}_{2}$ adsorbent, $100 \mathrm{~mL}$ of $5.0 \mathrm{mg}-\mathrm{AsL}^{-1}$ arsenic solution.

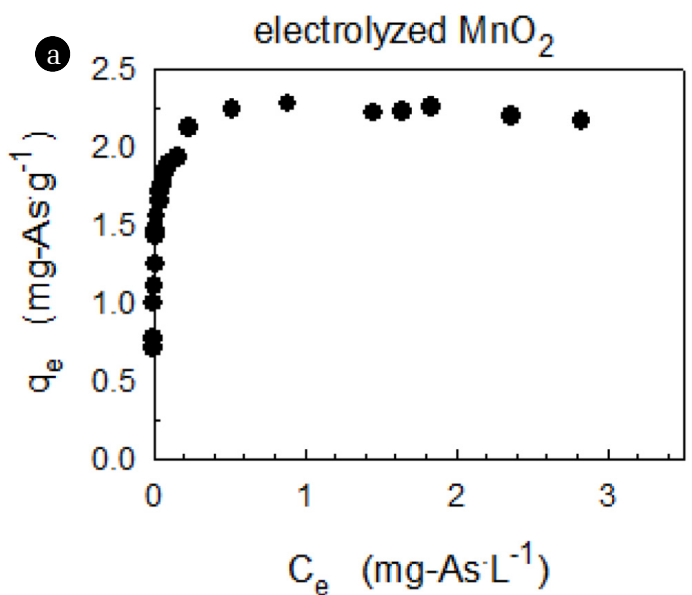

Since saturated adsorption amounts were observed for the two types of adsorbents, a Langmiur type of isotherm was expected to be in the range of less than 1 mg-As $\mathrm{L}^{-1}$ of the equilibrium concentration. In the case of the electrolyzed $\mathrm{MnO}_{2}$, however, the reciprocal of the adsorption amount $\left(1 / \mathrm{q}_{\mathrm{e}}\right)$ was not correlated linearly with the reciprocal of the equilibrium concentration $\left(1 / \mathrm{C}_{\mathrm{e}}\right)$ as shown in Fig. 4(a). Freundlich plot did not also show linear correlation (Fig. 4(c)). However, it was correlated linearly with $1 / \sqrt{C_{e}}$ (Fig. 4(b)), and the adsorption isotherm can be expressed by the following modified Langmuir equation:

$$
q_{e}=\frac{24.8 \sqrt{C_{e}}}{1+9.53 \sqrt{C_{e}}} \quad(\mathrm{r}=0.997)
$$

A similar relationship was observed for phosphate adsorption on a hydrotalcite compound [38]. This type of equation was well known in the case of chemisorption of hydrogen on metal surface [39, 40], where a hydrogen molecule occupies two adsorption sites. On the other hand, in the case of the calcined $\mathrm{MnO}_{2}$, both Langmuir and Freundlich equations gave similar correlation coefficients, which were smaller than that for the electrolyzed $\mathrm{MnO}_{2}$. The following two types of adsorption isotherms were used in the experimental results.

$$
\begin{gathered}
q_{e}=\frac{40.5 \sqrt{C_{e}}}{1+1.93 \sqrt{C_{e}}} \quad(\mathrm{r}=0.963) \\
q_{e}=2.51 C_{e}{ }^{0.163} \quad(\mathrm{r}=0.970)
\end{gathered}
$$

The results of X-ray diffraction (XRD), shown in Fig. 5, indicated the following: Electrolyzed $\mathrm{MnO}_{2}$ was composed of a hexagonal structure (-type) and the calcined $\mathrm{MnO}_{2}$ contained at least two types of tetragonal structures (pyrolusite and the other). Therefore, the calcined $\mathrm{MnO}_{2}$ may have a variety of adsorption energy levels of the active sites, and this may cause that the adsorption isotherm was not expressed by a Langmuir equation. The XRD patterns of the manganese dioxides after arsenate adsorption were not varied because of very low adsorption amounts.

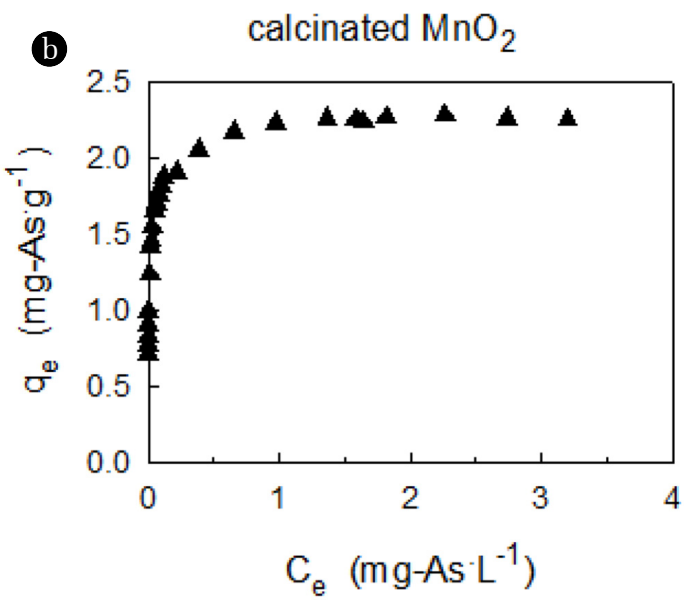

Fig. 3. Relationship between adsorption amount $\left(\mathrm{q}_{\mathrm{e}}\right)$ and concentration $\left(\mathrm{C}_{\mathrm{e}}\right)$. Conditions: temperature at $25^{\circ} \mathrm{C}, 48 \mathrm{~h}$ of reaction time. 

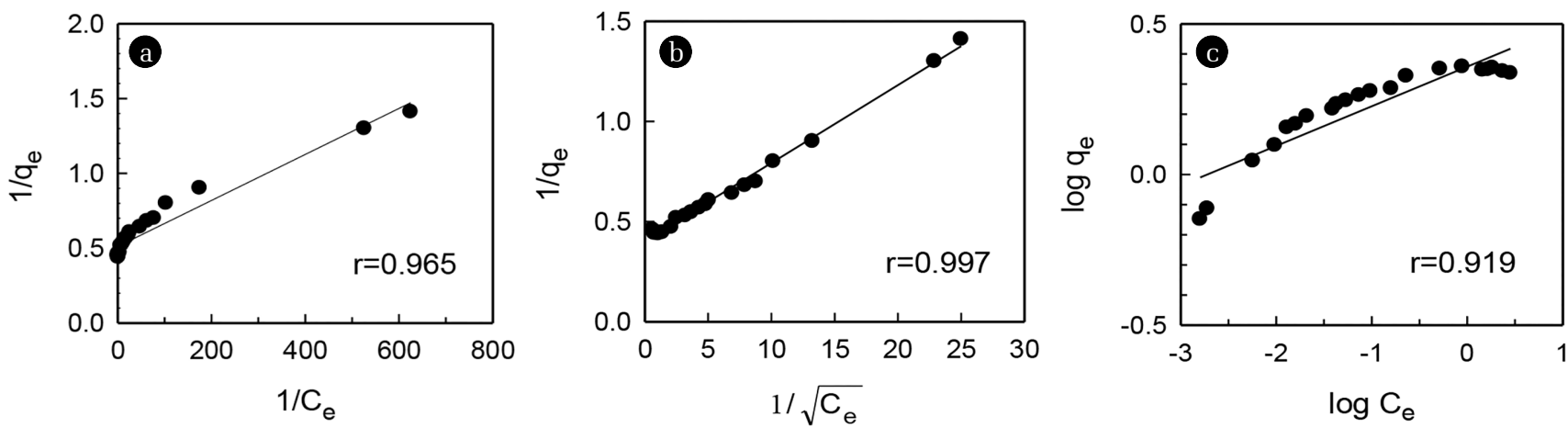

Fig. 4. Adsorption isotherm of the electrolyzed $\mathrm{MnO}_{2}\left(\mathrm{C}_{\mathrm{e}}<1 \mathrm{mg}-\mathrm{As} \cdot \mathrm{L}^{-1}\right)$. Conditions: temperature at $25^{\circ} \mathrm{C}, 48 \mathrm{~h}$ of reaction time.
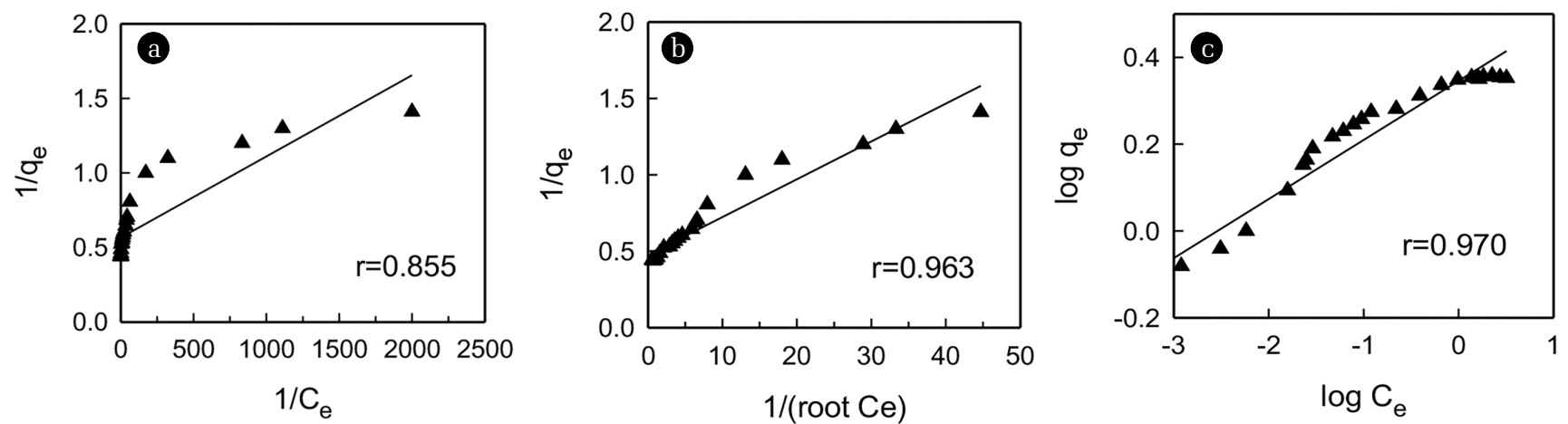

Fig. 5. Adsorption isotherm of the calcined $\mathrm{MnO}_{2}\left(\mathrm{C}_{\mathrm{e}}<1 \mathrm{mg}-\mathrm{As} \cdot \mathrm{L}^{-1}\right)$. Conditions: temperature at $25^{\circ} \mathrm{C}, 48 \mathrm{~h}$ of reaction time.

Although different adsorption isotherms were obtained for the two types of adsorbents, almost similar the maximum adsorption capacity amounts (2.26 or $2.22 \mathrm{mg}-\mathrm{As} \mathrm{g}^{-1}$ ) and the equilibrium adsorption amounts ( 1.20 or $1.27 \mathrm{mg}-A s^{-1}$ ) at $0.01 \mathrm{mg}^{-A s ~ \mathrm{~L}^{-1}}$ of the equilibrium concentration were almost the same for both types of $\mathrm{MnO}_{2}$.

The maximum adsorption capacity amounts of the electrolyzed and calcined $\mathrm{MnO}_{2}$ were similar, although the specific surface areas were significantly different. Considering the specific surface areas, the calcined $\mathrm{MnO}_{2}$ had a higher adsorption capacity per unit area. Even in the case of the calcined $\mathrm{MnO}_{2}$, the monolayer adsorption was suggested as follows: The occupied surface area by arsenate at the maximum adsorption amount was evaluated to be $3.8 \mathrm{~m}^{2} \mathrm{~g}^{-1}$, where the radius of the $\mathrm{AsO}_{4}{ }^{3-}$ ion is assumed to be $0.25 \mathrm{~nm}$. Since the crystalline structure may affect the adsorption capacity, it is important to clarify the adsorption mechanism in order to develop an effective $\mathrm{MnO}_{2}$ adsorbent.

In the case of the granular adsorbent, the saturated adsorption amount was $0.548 \mathrm{mg}$-As $\mathrm{g}^{-1}$ at more than $2.2 \mathrm{mg}^{-A s} \mathrm{~L}^{-1}$ of the equilibrium concentration, as shown in Fig. 6 . The ratio of the value against that of the powdered $\mathrm{MnO}_{2}$ (2.22 or 2.26 mg-As g ${ }^{-1}$ ) corresponded to the $\mathrm{MnO}_{2}$ content (23.2\%). The adsorption isotherm, in the range of less than $0.1 \mathrm{mg}-\mathrm{As} \mathrm{L}^{-1}$, was also approximated by the following modified Langmuir equation, which was similar to that of the electrolyzed $\mathrm{MnO}_{2}$ :

$$
q_{e}=\frac{3.69 \sqrt{C_{e}}}{1+6.80 \sqrt{C_{e}}} \quad(\mathrm{r}=0.967)
$$

The adsorption amount at $0.01 \mathrm{mg}-\mathrm{As} \mathrm{L}^{-1}$ of arsenic concentration, the drinking water standards for arsenic, was evaluated as 0.543 mg-As $\mathrm{g}^{-1}$. This value also corresponded to the content of $\mathrm{MnO}_{2}$ in the granular adsorbent.

Lin and $\mathrm{Wu}$ [15] examined the arsenate adsorption properties of the activated alumina (specific surface area: 115-118 $\mathrm{m}^{2} \mathrm{~g}^{-1}$ ) and the adsorption isotherm was analyzed by both the Langmuir and Freundlich equations. The Langmuir equation provided a better correlation than Freundlich equation and the maximum adsorption capacity was $15.90 \mathrm{mg}$-As $\mathrm{g}^{-1}$. However, the calculated adsorption amount at $0.01 \mathrm{mg}-\mathrm{As} \mathrm{L^{-1 }}$ of the equilibrium concentration was $1.41 \mathrm{mg}-\mathrm{As}$ $\mathrm{L}^{-1}$, which is similar to those of the powdered manganese dioxides. Guo et al. [8] reported that the adsorption isotherm of granular ferric hydroxide (specific surface area: 226-252 $\mathrm{m}^{2} \mathrm{~g}^{-1}$ ) for arsenate was expressed by Freundlich type, where the calculated adsorption amount at $0.01 \mathrm{mg}-\mathrm{As} \mathrm{L}{ }^{-1}$ was $7.98 \mathrm{mg}$-As $\mathrm{g}^{-1}$. The adsorption capacity amounts of these adsorbents are also listed in Table S1. The granular $\mathrm{MnO}_{2}$ showed a significantly lower adsorption capacity than the other adsorbents listed in Table 1. Considering that the $\mathrm{MnO}_{2}$ content of the granular $\mathrm{MnO}_{2}$ was low (23.3\%), it is necessary to increase the $\mathrm{MnO}_{2}$ content for improvement of the adsorption capacity.

For the adsorption processes, co-existing anions such as phosphate may influence adsorption capacity. It was reported that 0.1-2 $\mathrm{mg} \mathrm{L}^{-1}$ of phosphate and fluoride could reduce significantly the arsenic adsorption capacity [41]. Although the effects of fluoride ions have not been clarified in this work clearly, the adsorption capacity of the granular $\mathrm{MnO}_{2}$ for phosphate was also examined, and $0.188 \mathrm{mg}^{-\mathrm{P} \mathrm{g}^{-1}}$ of the maximum adsorption amount was 
Table 1. Summary for the Adsorption Amount by the Powder and the Granular Adsorbent

\begin{tabular}{|c|c|c|c|c|}
\hline adsornebt & Max. capacity (mg-As $\mathrm{g}^{-1}$ ) & Adsorbed amount (mg-As..$\left.^{-1}\right)$ at $\left.0.01 \mathrm{mg}-A s \mathrm{~L}^{-1^{*}}\right)$ & remark & Ref. \\
\hline electrolyzed & 2.22 & 1.27 & & \\
\hline calcinated & 2.26 & 1.20 & & \\
\hline granular & 0.548 & 0.290 & & \\
\hline Activated alumina & 15.90 & 1.41 & Langmuir type & [14] \\
\hline Ferric hydroxide & - & 7.98 & Freundlich type & [7] \\
\hline
\end{tabular}

*calculated by the adsorption isotherm
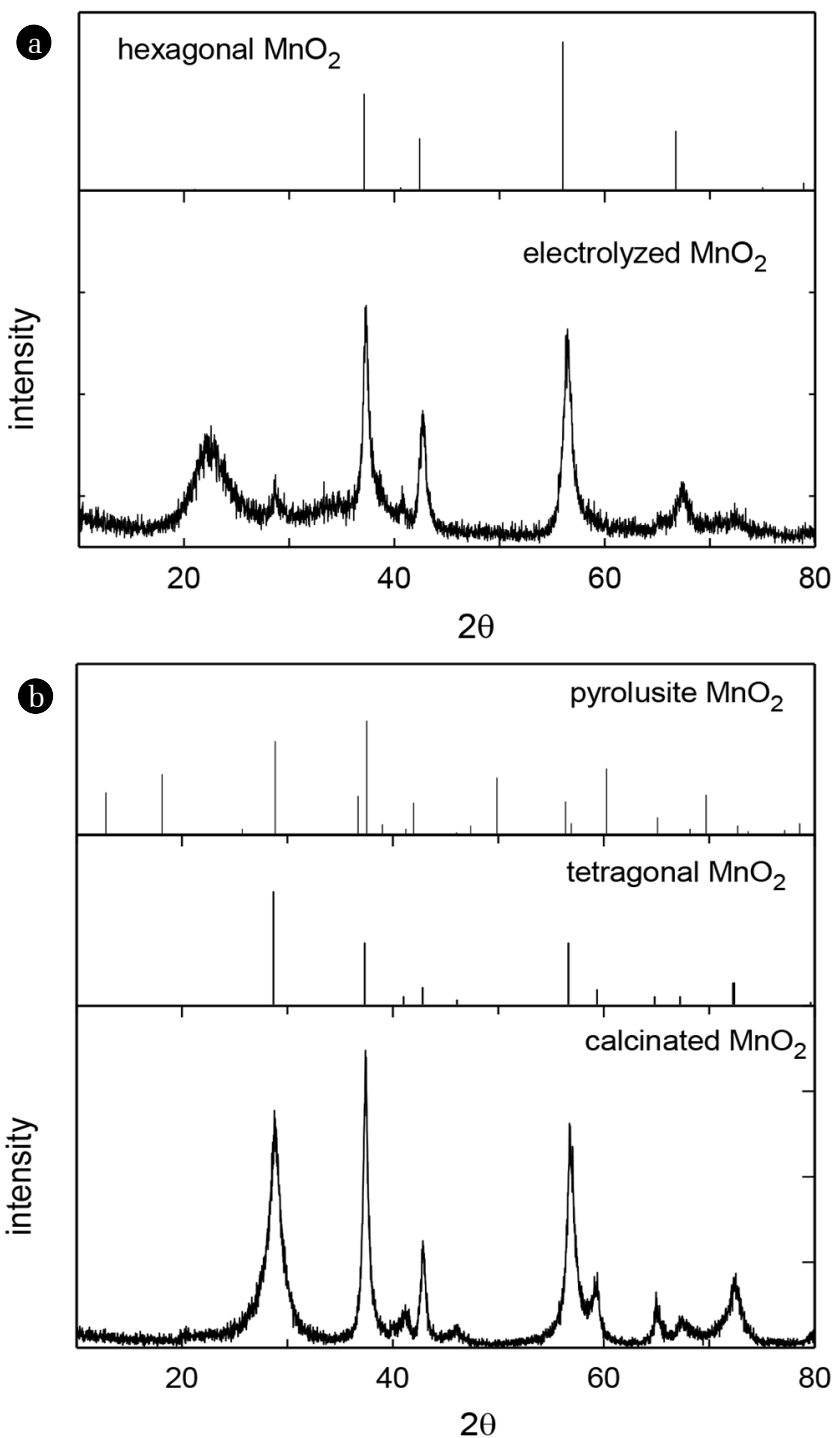

Fig. 6. X-ray diffractograms of electrolyzed $\mathrm{MnO}_{2}$ and calcined $\mathrm{MnO}_{2}$.

obtained. Since the mole adsorption capacity for arsenate and phosphate were almost the same, the co-existing phosphate may suppress the arsenate removal performance of $\mathrm{MnO}_{2}$ as shown in the effect of phosphate solutes on arsenate removal with hydrotalcite compound [42]. The selectivity between arsenate and phosphate should be examined by further research.

\subsection{Column Adsorption}

A solution containing 0.10 mg-As $\mathrm{L}^{-1}$ was fed into a column packed with granular adsorbent and the breakthrough curves are obtained as shown in Fig. 7. When the breakthrough point was $0.01 \mathrm{mg}$-As $\mathrm{L}^{-1}$, the ratios of the treated water volumes to the bed volume were evaluated to be 3880 for SV $=10 \mathrm{~h}^{-1}$ and 3,580 for SV = $20 \mathrm{~h}^{-1}$, respectively. The effect of SV was not significant under the flow conditions. Considering the operating conditions that the experiments were carried out with a short column (100 mm length), it was concluded that the arsenate was removed effectively even by $\mathrm{MnO}_{2}$.
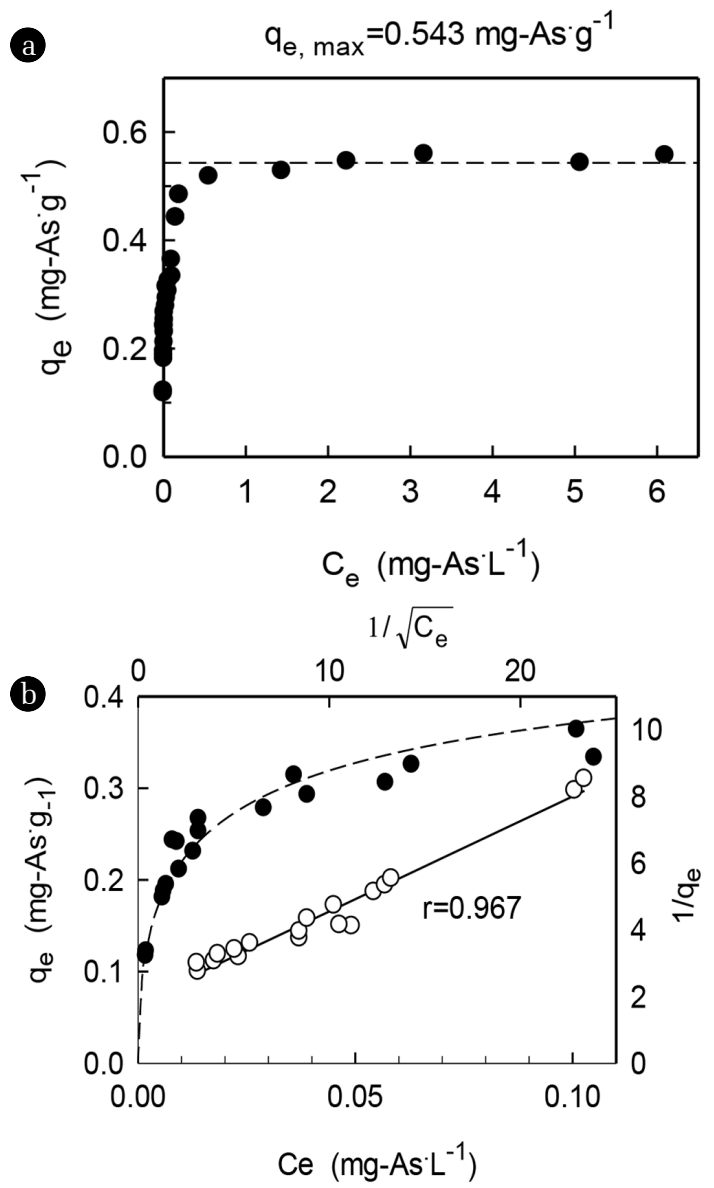

Fig. 7. Adsorption isotherm of the granulated $\mathrm{MnO}_{2}$. Conditions: temperature at $25^{\circ} \mathrm{C}, 10 \mathrm{~d}$ of reaction time. 
$\mathrm{MnO}_{2}$ is commonly used to remove manganese in the treatment of drinking water. In this process, chlorination is applied before feeding into the $\mathrm{MnO}_{2}$ column. In considering the process flow, arsenic is also removed simultaneously by this process. Since the manganese removal processes have been applied widely, the results obtained in this work may be of use in the design of an arsenic removal facility, although the effects of co-existing ions such as phosphate must be evaluated by further research.

\section{Conclusions}

The arsenate removal properties of manganese dioxides as adsorbents were investigated and the results obtained in this work are summarized as follows:

1) The removal increased with a decrease in the $\mathrm{pH}$ and stable removal rates (more than $80 \%$ ) were obtained with a $\mathrm{pH}$ range of less than 5.7 .

2) Saturated adsorption amounts were not significantly influenced by the type of $\mathrm{MnO}_{2}: 2.26 \mathrm{mg}-\mathrm{As} \mathrm{g}{ }^{-1}$ for the calcined $\mathrm{MnO}_{2}$ and $2.22 \mathrm{mg}^{-A s \mathrm{~g}^{-1}}$ for the electrolyzed $\mathrm{MnO}_{2}$ at more than $1 \mathrm{mg}-\mathrm{As}$ $\mathrm{L}^{-1}$ of the equilibrium concentration.

3) The adsorption isotherm for the electrolyzed $\mathrm{MnO}_{2}$ was approximated by a modified Langmuir equation, but the calcined $\mathrm{MnO}_{2}$ showed lower correlation factors for both Langmuir and Freundlich equations.

4) Considering that the $\mathrm{MnO}_{2}$ content of the granular $\mathrm{MnO}_{2}$ was low (23.3\%), it is necessary to increase the $\mathrm{MnO}_{2}$ content for improvement of the adsorption capacity.

5) When the solution containing $0.1 \mathrm{mg}-\mathrm{As}^{-1}$ was fed into the column packed with the granular $\mathrm{MnO}_{2}$, the breakthrough point was $0.01 \mathrm{mg}$-As $\mathrm{L}^{-1}$ and the ratios of the treated water volumes to the bed volume were evaluated to be 3,880 for $\mathrm{SV}=10 \mathrm{~h}^{-1}$ and 3,580 for $\mathrm{SV}=20 \mathrm{~h}^{-1}$, respectively.

\section{Author Contributions}

Y.J.J. (Professor) wrote the manuscript based on the experiment results. Y.K.(Professor) conducted the experiments and analyzed the experimental data.

\section{References}

1. Rahman A. Groundwater as source of contamination for water supply in rapidly growing megacities of Asia: case of Karachi, Pakistan. Water Sci. Technol. 1996;34:285-292.

2. Viraraghavan T, Subramanian KS, Aruldoss JA. Arsenic in drinking water-problems and solutions. Water Sci. Technol. 1995;40:69-76.

3. Kondo H, Ishiguro Y, Ohno K, Nagase M, Toba M, Takagi M. Naturally occurring arsenic in the ground waters in the southern region of Fukuoka Prefecture Japan. Water Res. 1999;33:1967-1972.

4. Paul BK. Arsenic contamination awareness among the rural residents in Bangladesh. Soc. Sic. Med. 2004;59:1741-1755.

5. WHO. Guidelines for drinking water quality. 2nd ed. Geneva:
World Health Organization; 1996.

6. Stroud JL, Norton GJ, Islam MR, et al. The dynamics of arsenic in four paddy fields in the Bengal delta. Environ. Pollut. 2011;159:947-953.

7. Meng X, Korfiatis GP, Christodoulatos C, Bang S. Treatment of arsenic in Bangladesh well water using a household co-precipitation and filtration system. Water Res. 2001;35:2805-2810.

8. Guo H, Wang Y, Shpeizer GM, Yan S. Natural occurrence of arsenic in shallow groundwater, Shanyin, Datong Basin, China. J. Environ. Sci. Heal A. 2003;38:2565-2580.

9. Wickramasinghe SR, Han B, Zimbron J, Shen Z, Karim MN. Arsenic removal by coagulation and filtration: Comparison of groundwaters from the United States and Bangladesh. Desalination 2004;169:231-244.

10. Soner Altundoğan HS, Tümen F. As(V) Removal from aqueous solutions by coagulation with liquid phase of red mud. J. Environ. Sci. Heal A. 2003;38:1247-1258.

11. Yuan T, Luo QF, Hu JY, Ong SL, Ng WJ. A study on arsenic removal from household drinking water. J. Environ. Sci. Heal A. 2003;38:1731-1744.

12. Gregor J. Arsenic removal during conventional aluminium-based drinking-water treatment. Water Res. 2001;35: 1659-1664.

13. Ning RY. Arsenic removal by reverse osmosis. Desalination 2002;143:237-241.

14. Brandhuber P, Amy G. Alternative methods for membrane filtration of arsenic from drinking water. Desalination 1998;117:1-10.

15. Lin TF, Wu JK. Adsorption of arsenite and arsenate within activated alumina grains: Equilibrium and kinetics. Water Res. 2001;35:2049-2057.

16. Sierra-Alvarez R, Field JA, Cortinas I, et al. Anaerobic microbial mobilization and biotransformation of arsenate adsorbed onto activated alumina. Water Res. 2005;39:199-209.

17. Pierce ML, Moore CB. Adsorption of arsenite and arsenate on amorphous iron hydroxide. Water Res. 1982;16:1247-1253.

18. Badruzzaman $M$, Westerhoff $P$, Knappe DRU. Intraparticle diffusion and adsorption of arsenate onto granular ferric hydroxide (GFH). Water Res. 2004;38:4002-4012.

19. Singh DB, Prasad D, Rupainwar DC. Adsorption technique for the treatment of As(V)-rich effluents. Colloid. Surf. A. 1996;111:49-56.

20. Zhang Y, Yang M, Huang X. Arsenic(V) removal with a Ce(IV)-doped iron oxide adsorbent. Chemosphere 2003;51:945-952.

21. Tokunaga S, Wasay SA, Park SW. Removal of arsenic(V) ion from aqueous solutions by lanthanum compounds. Water Sci. Technol. 1997;35:71-78.

22. Lorenzen L, Deventer JSJ, Landi WM. Factors affecting the mechanism of the adsorption of arsenic species on activated carbon. Min. Eng. 1995;8:557-569.

23. Dutta PK, Ray AK, Sharma VK, Millero FJ. Adsorption of arsenate and arsenite on titanium dioxide suspensions. J. Colloid. Interf. Sci. 2004;278:270-275.

24. Peng X, Luan Z, Zhang H, Tian B. Zirconia pillared montmorillonite for removal of arsenate from water. J. Environ. Sci. Heal. A. 2005;40:1055-1067.

25. Joshi A, Chaudhuri M. Removal of arsenic from ground water by iron oxide coated sand. J. Environ. Eng.-ASCE. 1996;122: 
769-771.

26. Singh DB, Prasad G, Rupainwar DC. Adsorption technique for the treatment of As(V)-rich effluents. Colloid. Surf. A. 1996;111:49-56.

27. Zouboulis AI, Katsoyiannis IA. Arsenic removal using iron oxide loaded aliginate beads. Ind. Eng. Chem. Res. 2002;41:6149-6155.

28. Lazaridis NK, Hourzemanoglou A, Matis KA. Flotation of metal-loaded clay anion exchangers. Part II: the case of arsenates. Chemosphere 2002;47:319-324.

29. Hodi M, Polyak K, Hlavay J. Removal of pollutants from drinking water by combined ion exchange and adsorption methods. Environ. Int. 1995;21:325-331.

30. Wasay SA, Parker W, Geel PJV, Barrington S, Tokunaga S. Arsenic pollution of a loam soil: Retention form and decontamination. Soil Sediment Contam. 2000;9:51-64.

31. Takamatsu T, Kawashima M, Koyama M. The role of $\mathrm{Mn}^{2+}$-rich hydrous manganese oxide in the accumulation of arsenic in lake sediments. Water Res. 1985;19:1029-1032.

32. Chakravarty S, Dureja V, Bhattacharyya G, Maity S, Bhattacharjee S. Removal of arsenic from groundwater using low cost ferruginous manganese ore. Water Res. 2002;36:625-632.

33. Driehaus W, Seith R, Jekel M. Oxidation of arsenate(III) with manganese oxides in water treatment. Water Res. 1995;29:297-305.

34. Borho M, Wilderer P. Optimized removal of arsenate(III) by adaptation of oxidation and precipitation processes to the filtra- tion step. Water Sci. Technol. 1996;34:25-31.

35. Japan Water Works Association 2004, Regulation A-103-3.

36. Kiso Y, Asaoka S, Kamimoto Y, Tanimoto S, Yokota K. Detection tube method for trace level arsenic. J. Env. Chem. Eng. 2015;3:40-45.

37. Morgan JJ, Stumm W. Colloid-chemical properties of manganese dioxide. J. Colloid. Sic. 1969;19:347-359.

38. Kindaichi T, Nishimura K, Kitao T, Kuzawa K, Kiso Y. Phosphorus removal with hydrotalcite compound -an application for secondary effluent of human excrement-. J. Jpn. Soc. Waste Manage. Experts 2002;13:99-105.

39. Zaitsev VN, Kholin YV, Gorlova EY, Khristenko IV. Silica chemically modified with $\mathrm{N}$-benzoyly- $\mathrm{N}$-phenylhydroxylamine in chemisorption of hydrogen and metal ions. Anal. Chim. Acta. 1999;379:11-21.

40. Saha D, Wei Z, Deng S. Hydrogen adsorption equilibrium and kinetics in metal-organic framework(MOF-5) synthesized with DEF approach. Sep. Puri. Technol. 2009; 64:280-287.

41. Jekel M. Removal of arsenic in drinking water treatment. in arsenic in the environment, Part I Cycling and characterization. Hoboken : Wiley; 1994. p. 119-132.

42. Kiso Y, Jung YJ, Yamamoto $\mathrm{H}$, et al. The effect of co-existing solutes on arsenate removal with hydrotalcite compound. Water Sci. Technol. 2010;61:1183-1188. 